\title{
Synthesis, Structural Characterization and Electrochemical Property of a Dinuclear Cu (II) Complex Material
}

\author{
Xi-Shi Tai ${ }^{*}, 1$ Xin Wang ${ }^{2}$ and Li Liu ${ }^{1}$ \\ ${ }^{1}$ College of Chemistry and Chemical Engineering, Weifang University, Weifang 261061, China \\ ${ }^{2}$ Department of Chemistry, Qinghai Normal University, Xining 810008, China
}

\begin{abstract}
A novel dinuclear $\mathrm{Cu}$ (II) complex material has been synthesized by the reaction of 1, 2-phenylenedioxydiacetic acid, 1,10-phenantroline (phen) and $\mathrm{Cu}\left(\mathrm{CH}_{3} \mathrm{COO}\right)_{2} \cdot \mathrm{H}_{2} \mathrm{O}$. And it has been characterized by elemental analysis, IR, UV and single crystal X-ray diffraction. The crystal belongs to tetragonal, space group I4 $1 / a$ with $a=b=25.381(4) \AA, c=$ 32.044(6) $\AA, V=20643(6) \AA^{3}, Z=16, D_{c}=1.395 \mathrm{~g} \cdot \mathrm{cm}^{-3}, \mu=0.898 \mathrm{~mm}^{-1}, F(000)=8896$, and final $R=0.1026, \omega R=$ 0.3142 . The structural analysis shows that two $\mathrm{Cu}(\mathrm{II})$ atoms adopt different coordination modes, $\mathrm{Cu}^{1}$ has five-coordination with a trigonal bipyramidal configuration, and $\mathrm{Cu}^{2}$ has four-coordination with a distorted square planar configuration. The cyclic voltammetric behaviour of the dinuclear $\mathrm{Cu}(\mathrm{II})$ complex has been investigated.
\end{abstract}

Keywords: Characterization, crystal structure, cyclic voltammetric property, dinuclear $\mathrm{Cu}(\mathrm{II})$ complex.

\section{INTRODUCTION}

The design and synthesis of $\mathrm{Cu}$ (II) complex have always attracted considerable interest, as the $\mathrm{Cu}$ (II) complexes have potential applications in so many respects. For example, they can build intriguing molecular architectures [1, 2], and can exhibit excellent properties in molecular magnetism, catalysis, antitumor therapeutic agents, and electrochemistry [3-10]. Both carboxylates and phen are good organic ligand because they not only have rich coordination points and strong coordination ability but can also construct the molecular structure of multiple structures [11-13]. We have synthesized a novel dinuclear $\mathrm{Cu}$ (II) complex by the selfassembly of 1, 2-phenylenedioxydiacetic acid, 1,10phenantroline (phen) and $\mathrm{Cu}\left(\mathrm{CH}_{3} \mathrm{COO}\right)_{2} \cdot \mathrm{H}_{2} \mathrm{O}$ in the presence of $\mathrm{MgCl}_{2}$ [14]. For comparison, we synthesized and reported herein another novel dinuclear $\mathrm{Cu}(\mathrm{II})$ complex, based on 1,2-phenylenedioxydiacetic acid and phen ligands without the presence of $\mathrm{MgCl}_{2}$. The cyclic voltammetric behaviour of the $\mathrm{Cu}$ (II) complex has also been investigated.

\section{EXPERIMENTAL SECTION}

\section{Materials and Methods}

1,2-Phenylenedioxydiacetic acid, 1,10-phenanthroline, $\mathrm{Cu}\left(\mathrm{CH}_{3} \mathrm{COO}\right)_{2} \cdot \mathrm{H}_{2} \mathrm{O}$ and solvents used were of analytical grade.

$\mathrm{C}, \mathrm{H}$ and $\mathrm{N}$ analyses were carried out with a Elementar Vario III EL elemental analyzer. Infrared spectra $\left(4,000 \mathrm{~cm}^{-1}\right.$ $\sim 400 \mathrm{~cm}^{-1}$ ) were recorded on a Nicolet AVATAR 360 FTIR spectrophotometer with $\mathrm{KBr}$ discs. Ultraviolet-Visible

*Address correspondence to this author at the College of Chemistry and Chemical Engineering, Weifang University, Weifang 261061, China;

Tel: +86-536-8785363; Fax: +86-536-8785363;

E-mails: taixishi@lzu.edu.cn, taixs@wfu.edu.cn spectra in the $200-700 \mathrm{~nm}$ region in $\mathrm{H}_{2} \mathrm{O}$ solution were recorded on a thermo UV-340 spectrophotometer. CHI660D electrochemical work station was used. The crystal data of dinuclear $\mathrm{Cu}$ (II) complex was collected on a Bruker smart1000 CCD Area Detector.

\section{Synthesis of Cu (II) Complex}

$1.0 \mathrm{mmol}(0.2262 \mathrm{~g})$ 1,2-phenylenedioxydiacetic acid and $2.0 \mathrm{mmol}(0.08 \mathrm{~g})$ of sodium hydroxide were dissolved in $10 \mathrm{~mL} \mathrm{CH}{ }_{3} \mathrm{OH} / \mathrm{H}_{2} \mathrm{O}(\mathrm{v}: \mathrm{v}=1: 1)$ solution. Then $0.5 \mathrm{mmol}$ $(0.0998 \mathrm{~g}) \mathrm{Cu}\left(\mathrm{CH}_{3} \mathrm{COO}\right)_{2} \cdot \mathrm{H}_{2} \mathrm{O}$ and $1.0 \mathrm{mmol}(0.0990 \mathrm{~g})$ phen were added to the above solution. The mixed solution was continuously stirred for $4 \mathrm{~h}$ at $80{ }^{\circ} \mathrm{C}$. The green precipitate was collected by filtration and washed with ethanol, then dried. The filtrate was evaporated in air at room temperature, the single crystal suitable for X-ray determination was obtained after 15 days. Elementary analysis: calcd for $\mathrm{C}_{49} \mathrm{H}_{40} \mathrm{Cu}_{2} \mathrm{~N}_{4} \mathrm{O}_{17}: \mathrm{C}, 54.25 ; \mathrm{H}, 3.69 ; \mathrm{N}$, 5.17\%; found: C, 53.92; H, 3.37; N, 4.79\%. IR $v_{\max }\left(\mathrm{cm}^{-1}\right)$ : $\mathrm{v}\left(\mathrm{H}_{2} \mathrm{O}\right): 3427 \mathrm{~cm}^{-1}, \mathrm{v}_{\mathrm{as}}\left(\mathrm{COO}^{-}\right): 1564 \mathrm{~cm}^{-1}, \mathrm{v}_{\mathrm{s}}\left(\mathrm{COO}^{-}\right): 1415$ $\mathrm{cm}^{-1}, \mathrm{v}(\mathrm{C}-\mathrm{O}-\mathrm{C}): 1222 \mathrm{~cm}^{-1}$.

\section{X-Ray Crystallography}

All crystal data were collected on a Bruker Smart-1000 CCD diffractometer equipped with a graphite-monochromatic Mo $K \alpha$ radiation $(\lambda=0.71073 \AA)$ at $293(2) K$. In the range $3.01-27.48^{\circ}$, a total of 88570 reflections were collected by using an $\omega$ scan mode, of 6465 with $I>2 \sigma(I)$ were independent with $R_{\text {int }}=0.0621$. The structure was solved by direct method and refined with full-matrix leastsquares techniques using SHELXL-97 [15]. All nonhydrogen atoms were refined anisotropically, and all hydrogen atoms were added according to the theoretical model. Molecular graphics were drawn with the program package SHELXTL-97 crystallographic software package 
[16]. The crystal parameters data collection and refinement results for dinuclear $\mathrm{Cu}(\mathrm{II})$ complex are summarized in Table 1. The selected bond distances and angles are listed in Table 2.

Table 1. Crystal data and structure refinement for $\mathrm{Cu}$ (II) complex.

\begin{tabular}{|c|c|}
\hline Crystal Parameter & Crystallographic Data \\
\hline Formula & $\mathrm{C}_{49} \mathrm{H}_{40} \mathrm{Cu}_{2} \mathrm{~N}_{4} \mathrm{O}_{17}$ \\
\hline Formula weight & 1083.93 \\
\hline Crystal system & tetragonal \\
\hline Space group & $\mathrm{I} 41 / \mathrm{a}$ \\
\hline$a(\AA)$ & $25.381(4)$ \\
\hline$b(\AA)$ & $25.381(4)$ \\
\hline$c(\AA)$ & $32.044(6)$ \\
\hline $\mathrm{Z}$ & 16 \\
\hline$F(000)$ & 8896 \\
\hline Temperature $(\mathrm{K})$ & 293(2) \\
\hline$V\left(\AA^{3}\right)$ & 20643(6) \\
\hline Calculated density $\left(\mu \mathrm{g} \cdot \mathrm{m}^{-3}\right)$ & 1.395 \\
\hline Crystal size $\left(\mathrm{mm}^{3}\right)$ & $0.24 \times 0.22 \times 0.20$ \\
\hline$\mu\left(\mathrm{mm}^{-1}\right)$ & 0.898 \\
\hline$S$ & 1.959 \\
\hline Limiting indices & $\begin{array}{c}-22 \leq h \leq 23 \\
0 \leq k \leq 32 \\
0 \leq l \leq 41\end{array}$ \\
\hline Reflections collected/unique & $11825 / 6420$ \\
\hline$R_{1}, w R_{2}$ [all data] & $0.1472,0.3347$ \\
\hline$R_{1}, w R_{2}[I>2 \sigma(I)]$ & $0.1026,0.3142$ \\
\hline Largest diff.peak and hole $\left(\mathrm{e} \cdot \AA^{-3}\right)$ & $2.497,-0.878$ \\
\hline
\end{tabular}

Table 2. Selected bond distances $(\AA)$ ) and angles $\left(^{\circ}\right)$ for $\mathrm{Cu}(\mathrm{II})$ complex.

\begin{tabular}{|c|c|c|c|}
\hline Bonds & Bond Parameter & Bonds & Bond Parameter \\
\hline \hline $\mathrm{Cu} 1-\mathrm{O} 14$ & $1.936(5)$ & $\mathrm{Cu} 2-\mathrm{O} 7$ & $1.898(5)$ \\
\hline $\mathrm{Cu} 1-\mathrm{O} 11$ & $1.963(5)$ & $\mathrm{Cu} 2-\mathrm{O} 4$ & $1.962(5)$ \\
\hline $\mathrm{Cu} 1-\mathrm{N} 4$ & $2.036(6)$ & $\mathrm{Cu} 2-\mathrm{N} 2$ & $1.995(6)$ \\
\hline $\mathrm{Cu} 1-\mathrm{O} 12$ & $2.347(5)$ & $\mathrm{Cu} 2-\mathrm{N} 1$ & $1.995(6)$ \\
\hline $\mathrm{Cu} 1-\mathrm{N} 3$ & $2.036(5)$ & & \\
\hline O14-Cu1-O11 & $92.3(2)$ & O4-Cu2-O7 & $92.1(2)$ \\
\hline O14-Cu1-N4 & $166.2(2)$ & O7-Cu2-N2 & $173.5(2)$ \\
\hline O11-Cu1-N4 & $94.1(2)$ & O4-Cu2-N2 & $94.3(2)$ \\
\hline O14-Cu1-N3 & $89.7(2)$ & O7-Cu2-N1 & $92.8(3)$ \\
\hline N3-Cu1-O11 & $166.4(2)$ & O4-Cu2-N1 & $155.6(2)$ \\
\hline N4-Cu1-N3 & $81.3(2)$ & N2-Cu2-N1 & $81.0(3)$ \\
\hline O12-Cu1-O14 & $97.58(18)$ & O12-Cu1-N4 & $93.41(18)$ \\
\hline O11-Cu1-O12 & $99.94(19)$ & O12-Cu1-N3 & $93.12(19)$ \\
\hline
\end{tabular}

\section{RESULTS AND DISCUSSION}

\section{IR Spectra}

The free 1,2-phenylenedioxydiacetic acid and phen ligands show bands at $1670 \mathrm{~cm}^{-1} v\left(\mathrm{COO}^{-}\right)$and $1582 \mathrm{~cm}^{-1}$ $v(\mathrm{C}=\mathrm{N})$ of phen, respectively. In the IR spectrum of $\mathrm{Cu}$ (II) complex (Fig. 1), they appear at $1564 \mathrm{~cm}^{-1}$ and $1513 \mathrm{~cm}^{-1}$, respectively, which indicates that the oxygen atoms of $\mathrm{COO}^{-}$ and the nitrogen atoms of phen are coordinated to $\mathrm{Cu}$ (II) ion [17]. The results of IR analysis are consistent with the results of X-ray analysis.

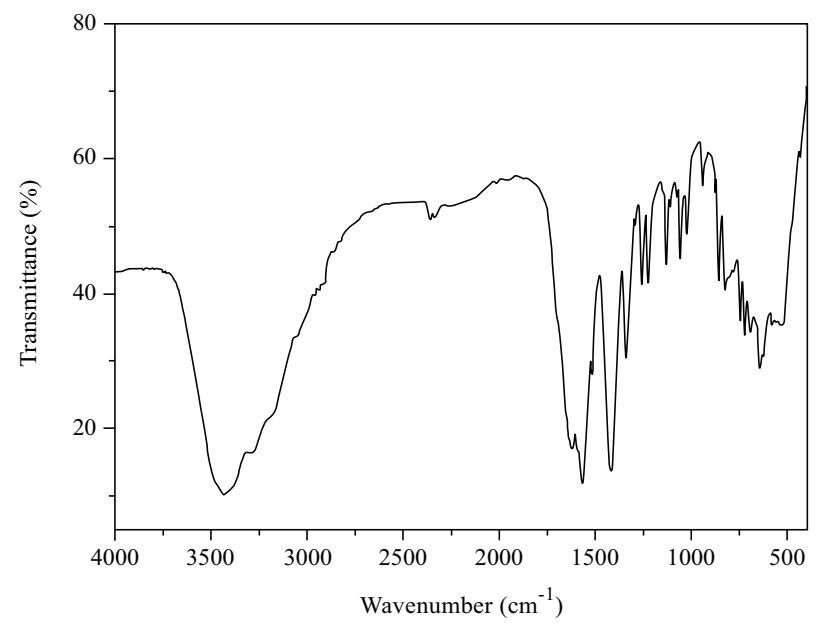

Fig. (1). The IR spectrum of the $\mathrm{Cu}(\mathrm{II})$ complex.

\section{UV Spectra}

As shown in Fig. (2), the free 1, 2-phenylenedioxydiacetic acid ligand exhibits two absorption bands at $224 \mathrm{~nm}$ and $271 \mathrm{~nm}$, which can be assigned to the $\pi-\pi$ transitions of the organic ligand. However, the $\mathrm{Cu}$ (II) complex show three peaks at $221 \mathrm{~nm}, 273 \mathrm{~nm}$ and $600 \mathrm{~nm}$. The two absorption bands at $221 \mathrm{~nm}$ and $273 \mathrm{~nm}$ can be assigned to the $\pi-\pi$ transitions and the absorption at $600 \mathrm{~nm}$ can be assigned to $\mathrm{d}-\mathrm{d}$ transition. Which indicates that the stable complex is formed by the interaction of ligand and the $\mathrm{Cu}$ (II) ion.

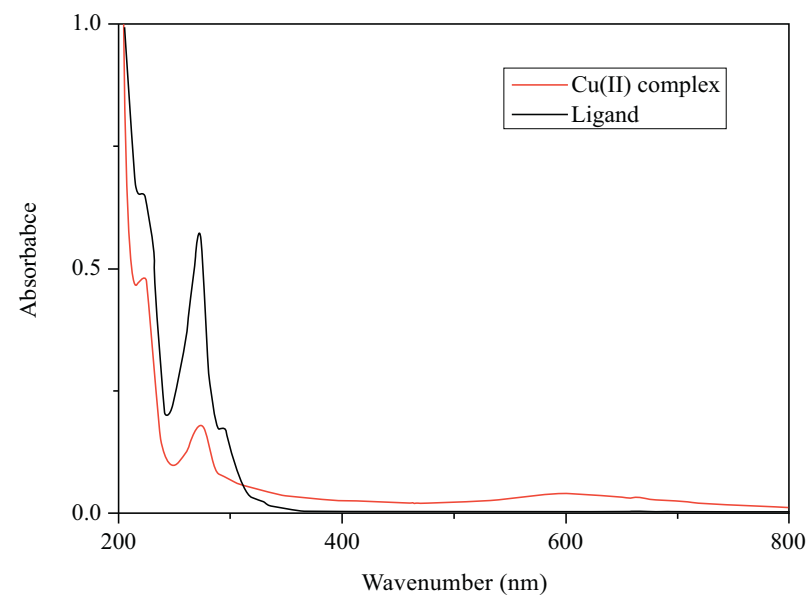

Fig. (2). The UV-vis spectra of 1, 2-phenylenedioxydiacetic acid and its $\mathrm{Cu}(\mathrm{II})$ complex. 


\section{Structure Description}

The molecular structure and molecular packing arrangement are shown in Figs. $(\mathbf{3}, \mathbf{4})$, respectively. Fig. (5) shows the topological structure of the $\mathrm{Cu}$ (II) complex. The structure of $\mathrm{Cu}$ (II) is different from that of the $\mathrm{Cu}$ (II) complex reported previously [14], indicating that the same ligand and metal ion can form different structure when the synthetic condition was changed. As shown in Figs. $(\mathbf{3}, \mathbf{4})$, the $\mathrm{Cu}^{1}$ ion is five-coordinated by two oxygen atoms from 1 , 2-phenylenedioxydiacetic acid ligand, one oxygen atom from coordinated water molecule and two nitrogen atoms from phen ligand to form a distorted square pyramid coordination environment. And the $\mathrm{Cu}^{2}$ ion is fourcoordinated by two oxygen atoms from 1,2phenylenedioxydiacetic acid ligand and two nitrogen atoms from phen ligand to form a distorted square planar coordination environment. The bond distances of $\mathrm{Cu}-\mathrm{O}$ are in the range of 1.898(5) $\AA-2.347(5) \AA$, and that of $\mathrm{Cu}-\mathrm{N}$ bonds are in the range of 1.995(6)-2.036(5) $\AA$, respectively. The $\mathrm{Cu}-\mathrm{O}$ distances and $\mathrm{Cu}-\mathrm{N}$ distances are close to those of the $\mathrm{Cu}$ (II) complex reported previously [18-20].
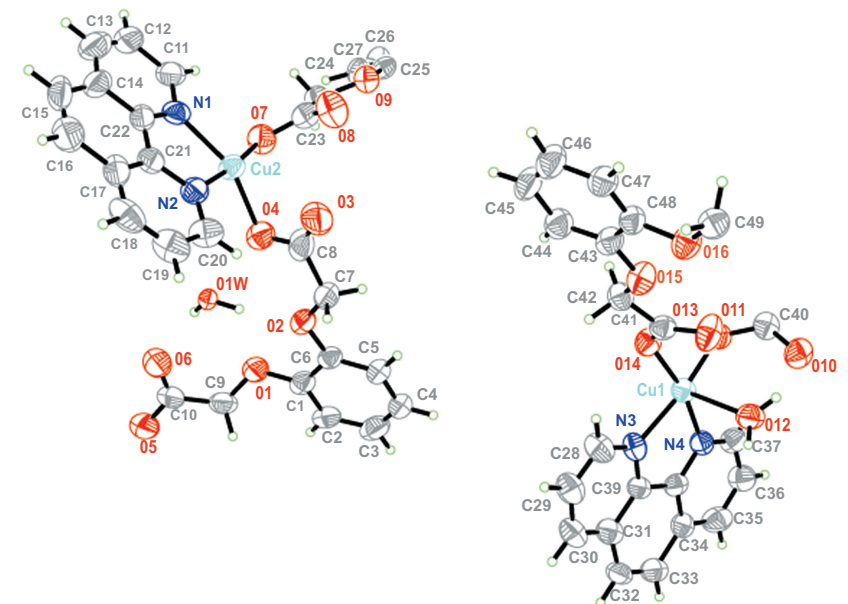

Fig. (3). The molecular structure of the asymmetric unit of $\mathrm{Cu}(\mathrm{II})$ complex.

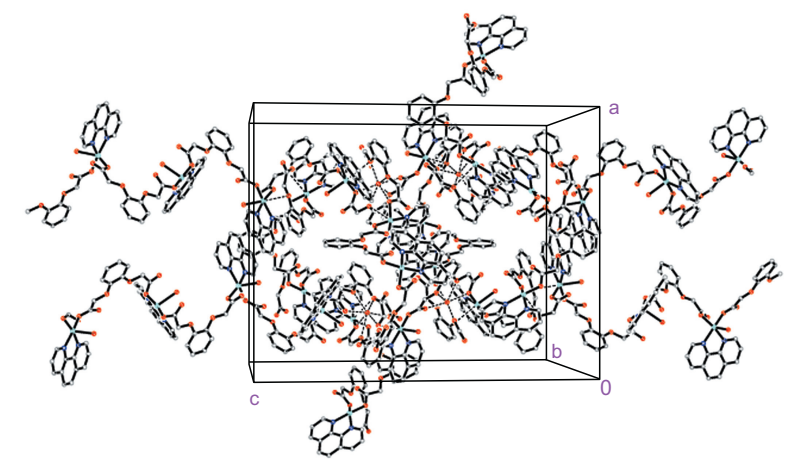

Fig. (4). The molecular packing arrangement of the $\mathrm{Cu}(\mathrm{II})$ complex.

\section{Cyclic Voltammetry of $\mathrm{Cu}$ (II) Complex}

The electrochemical behavior of the $\mathrm{Cu}$ (II) complex was determined, and the process of measurement is the same with those reported previously [14]. As shown in Fig. (6), there appears an obvious oxidation peak at $391 \mathrm{mV}$, however, no reduction peak is observed, showing that the $\mathrm{Cu}(\mathrm{II})$ complex only has reducibility and no oxidizability.

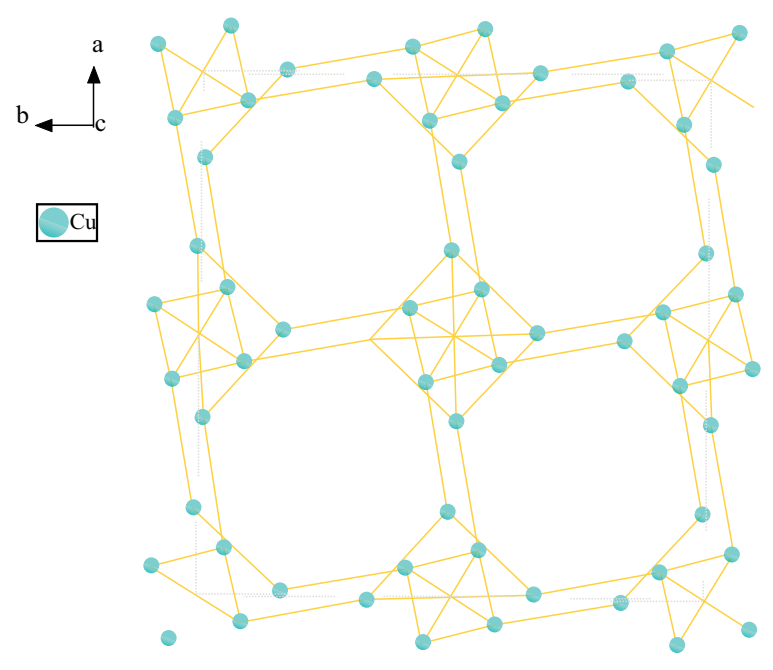

Fig. (5). The topological structure of the $\mathrm{Cu}(\mathrm{II})$ complex.

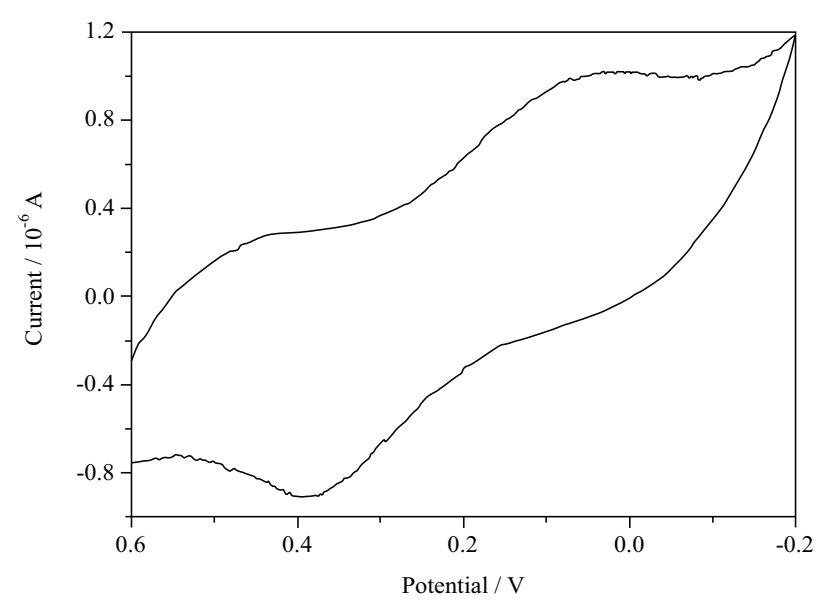

Fig. (6). The cyclic voltammogram using phosphate buffer $(\mathrm{pH}=$ 6.86).

\section{CONCLUSION}

A novel dinuclear $\mathrm{Cu}$ (II) complex, based on 1, 2phenylenedioxydiacetic acid and 1,10-phenantroline (phen) ligands without the presence of $\mathrm{MgCl}_{2}$ has been synthesized with structural characterization. In this structure, the $\mathrm{Cu}$ (II) atoms adopt two different coordination modes. The cyclic voltammetric behavior of the dinuclear $\mathrm{Cu}$ (II) complex has been investigated.

\section{CONFLICT OF INTEREST}

The authors confirm that this article content has no conflict of interest.

\section{ACKNOWLEDGEMENTS}

The authors would like to thank the National Natural Science Foundation of China (No. 21171132), the Project of 
Shandong Province Higher Educational Science and Technology Program (J14LC01) and the Natural Science Foundation of Shandong (ZR2014BL003).

\section{SUPPLEMENTARY MATERIAL}

Crystallographic data for the structure reported in this paper has been deposited with the Cambridge Crystallographic Data Centre as supplementary publication No. CCDC 1030752. Copy of the data can be obtained free of charge on application to CCDC, 12 Union Road, Cambridge CB2 1EZ, UK (Fax: +44-1223-336-033; E-Mail: deposit@ccdc.cam.ac.uk).

\section{REFERENCES}

[1] Marino N, Armentano D, Mastropietro TF, et al. cubane-type $\mathrm{Cu}(\mathrm{II}) 4$ and $\mathrm{Mn}(\mathrm{II}) 2 \mathrm{Mn}(\mathrm{III}) 2$ complexes based on pyridoxine: a versatile ligand for metal assembling. Inorg Chem 2013; 52: 11934-43.

[2] Gusev AN, Nemec I, Herchel R, et al. Versatile coordination modes of bis[5-(2-pyridine-2-yl)-1,2,4-triazole-3-yl]alkanes in $\mathrm{Cu}(\mathrm{II})$ complexes. Dalton Trans 2014; 43: 7153-65.

[3] Xie QW, Tong HB, Zhou MS. Synthesis, structure, and magnetic properties of novel 1,3,5-triazapentadienyl copper(II) complexes $\left[\mathrm{N}\left(2,6-\mathrm{iPr} 2-\mathrm{C}_{6} \mathrm{H}_{3}\right) \mathrm{C}\left(\mathrm{NMe}_{2}\right) \mathrm{NC}\left(\mathrm{NMe}_{2}\right) \mathrm{N}\left(\mathrm{SiMe}_{3}\right)\right] \mathrm{CuCl}$ and $[\mathrm{N}(\mathrm{Ph})$ $\left.\mathrm{C}\left(\mathrm{NMe}_{2}\right) \mathrm{NC}\left(\mathrm{NMe}_{2}\right) \mathrm{N}\left(\mathrm{SiMe}_{3}\right)\right]_{2} \mathrm{Cu}$. Inorg Chem Commun 2014; 44: 37-40.

[4] Nfor EN, Majoumo-Mbe F, Ndifon PT, et al. Synthesis, crystal structure, and magnetic properties of Bis(aqua) $[\mu$-(terepthalato$\left.\left.\kappa o, \kappa 0^{\prime}\right)\right]$ copper(II)monohydrate $\left[\mathrm{Cu}\left(\mathrm{C}_{8} \mathrm{O}_{4}\right)\left(\mathrm{OH}_{2}\right)_{2}\right] \cdot \mathrm{H}_{2} \mathrm{O}$. J Solid State Chem 2013; 201: 133-6.

[5] Wang SX, Chu WH, Wang YC, et al. Synthesis, characterization and cytotoxicity of $\mathrm{Pt}(\mathrm{II}), \mathrm{Pd}(\mathrm{II}), \mathrm{Cu}(\mathrm{II})$ and $\mathrm{Zn}(\mathrm{II})$ complexes with 4'-substituted terpyridine. Appl Organomet Chem 2013; 27: 373-9.

[6] Zhou CQ, Lin YL, Yang JW, et al. Synthesis, DNA-cleaving activities and cytotoxicities of C2-symmetrical dipyrrolepolyamide dimer-based $\mathrm{Cu}(\mathrm{II})$ complexes: a comparative study. Eur J Med Chem 2013; 66C: 508-15.

[7] Li LM, Liu L, Zeng WL, et al. Investigation into the crystal structure of bis(pyridine)-bis(trichloroacetato) copper(II) and its electrophotochemical properties. Res Chem Intermed 2013; 39: 1727-34.

[8] Tai XS, Liu L, Zhao WH. Synthesis, crystal structure, and electrochemical properties of the complex of $\mathrm{Cu}(\mathrm{II})$ with 3 ethoxysalicylaldehyde-N,N-bis(3-aminopropyl)methylamine. Res Chem Intermed 2015; 41: 785-92.

[9] Huang ST, Yang LF, Li NB, et al. An ultrasensitive and selective fluorescence assay for sudan I and III against the influence of sudan II and IV. Biosens Bioelectron 2012; 5: 1626-34.

[10] Manuela M. ESI-MS study of self-assembly-formed tetraglycine macrocyclic ligand complex of $\mathrm{Cu}$ (II). Int J Mass Spectrom 2013; 351: $12-22$.

[11] Liu H, Yang GS, Liu CB, et al. Syntheses, crystal structures, and antibacterial activities of helical M (II) phenyl substituted pyrazole carboxylate complexes. J Coord Chem 2014; 67: 572-87.

[12] Yu XK, Weng WD, Guo XX, et al. Preparation, crystal structure and magnetic properties of two 1,2-Di(4-pyridyl)ethylene-bridged manganese(II) complexes. J Inorg Organomet Polym 2013; 23 : 1451-8.

[13] Gui G, Zhou Y, Chai YQ, et al. Supersandwich-type electrochemiluminescenct aptasensor based on $\mathrm{Ru}($ phen) $32+$ functionalized hollow gold nanoparticles as signal-amplifying tags. Biosens Bioelectron 2013; 47: 524-9.

[14] Tai XS, Liu L, Yin J. Synthesis, spectral characterization and electrochemical property of $\mathrm{Cu}$ (II) complex with 1, 2-phenylenedioxydiacetic acid and 1,10-phenanthroline. Res Chem Intermed 2014, DOI: 10.1007/s11164-014-1891-3.

[15] Sheldrick GM. SHELXL-97, Program for crystal structure solution. University of GÖttingen: GÖttingen, Germany 1997.

[16] Sheldrick GM. SHELXTL-97, Program for crystal structure refinement. University of GÖttingen: GÖttingen, Germany 1997.

[17] Nakamoto K. Infrared and ramen spectra of inorganic and coordination compounds. $3^{\text {rd }}$ ed. John Wiley and Sons: New York, NY, USA 1978; 1: pp. 359-68,

[18] Tai XS, Liu LL, Yin J. Synthesis, crystal structure of tetra-nuclear macrocyclic cu (ii) complex material and its application as catalysts for A3 coupling reaction. J Inorg Organomet Polym 2014; 24: 1014-20.

[19] Lin CJ, Qi JL, Zheng YQ, et al. Two new $\mathrm{Cu}$ (II) $\mathrm{m}$ hydroxybenzoato complexes with chloro- and carboxylato-bridged dinuclear $[\mathrm{Cu}(\mu 2-\mathrm{Cl})(\mu 2-\mathrm{COO}) \mathrm{Cu}]$ cores. J Coord Chem 2013; 66: 3877-90.

[20] Mohan NP, Promise AD, Bhupesh SB. Synthesis, characterization, antibacterial activity and DNA interaction studies of drug-based mixed ligand copper (II) complexes with terpyridines. Med Chem Res 2012; 21: 2723-33. 